\title{
NARRATING "HISTORIES OF SPAIN". STUDENT TEACHERS AND THE CONSTRUCTION OF NATIONAL NARRATIVES ${ }^{1}$
}

\author{
Cosme J. Gómez Carrasco, University of Murcia, Spain \\ Ramón López Facal, University of Santiago de Compostela, Spain \\ Jorge Sáiz Serrano, University of Valencia, Spain
}

\begin{abstract}
This study analyses the role of Spanish teacher training students as narrators of what they consider to be the history of Spain. Results of this empirical study are based on a random sample of 103 narratives produced by trainee primary education teachers (20-22 years of age) studying at the University of Murcia. We are interested in understanding the role of students as agents of historical knowledge.
\end{abstract}

Recent research in history education has stressed the need to vindicate the active role of students in the creation of historical narratives. How do students construct their accounts of history? How do they reflect narratives of school-taught history? Their narratives always reveal certain forms and skills employed to represent the past. This study focuses on this perspective. We have analysed their extra-curricular knowledge (family, social environments, mass media and other cultural products such as TV series, videogames, websites, etc.) and their memories of school history (curriculum, textbooks, teachers) using a mixed quantitative and qualitative methodology.

Our qualitative methodology is based on grounded theory and, in order to analyse discourse, we have used quantitative methodology with the analysis of key events and historical figures present in the narrative, in an attempt to categorise second order concepts and sources of historical knowledge. In the results, essentialist and traditional representations of this historical knowledge can be appreciated.

Reported major events are related to a traditional political reading of history and linked to genesis and nation-building events: showing heroes and antiheroes of a national narrative. Regarding the sources of knowledge, teachers' explanations, textbooks and museums are the factors most valued by students.

\section{Keywords:}

Historical thinking, History education, National narratives, Students' narratives

\section{Introduction}

When it comes to research on the teaching of history today, two issues stand out as being particularly significant; the reasoning of students with regard to history and their narrative representations of the past. Over the course of the last two decades, research on narrative thought has been tackled in an interdisciplinary manner, both from the point of view of social

1 This paper is the result of research project EDU2015-65621-C3-R "Competencias sociales para una ciudadanía democrática: análisis, desarrollo y evaluación"; EDU2015-65621-C3-2-R "La evaluación de las competencias y el desarrollo de capacidades cognitivas sobre historia en Educación Secundaria Obligatoria"; EDU2014-51720REDT RED 14 "Red de investigación en enseñanza de las ciencias sociales" 
science and from the humanities (Liu, 2013). As far as the teaching of history and other areas of the social sciences is concerned, the analysis of narratives constitutes a significant line of research (Henríquez \& Ruiz, 2014). This process has occurred in parallel with historiographical discussions regarding the value of narration in the explanation of history (Ankersmit, 2001). Historical knowledge and the construction of narratives are closely linked (Carretero, Van Alphen, 2014), with narratives of historical topics (explanatory accounts and reasoning based on the use of sources) constituting fundamental instruments for researching and teaching the development of historical thought at different levels of education. Narratives of a historical nature (explanatory accounts and reasoning based on sources) are fundamental tools for researching and teaching the development of historical thought at different levels of education. The analysis of these narratives is approached, above all, from a qualitative perspective, applying a hermeneutical and phenomenological focus (Carretero \& Van Alphen, 2014; Chapman, 2011; López, Carretero \& Rodríguez-Moneo, 2014; Monte-Sano, 2010). However, the field of social psychology has also made advances by combining these qualitative methods with quantitative techniques which enable social representations to be researched via the use of narratives (Fülöp, Lázsló, 2013; Lázlo, 2008; McAdams, 2006).

In fact, research on the public uses of history and the function of history teaching highlight the close relationship between history and nationalism and the construction of national identities. The contents of the school history syllabus, enshrined in textbooks, include the characteristics of a national narrative as a metanarrative of the past of a nation as an imagined community. This fact can also be noted in history teaching in Spain (Álvarez Junco, 2013; Gómez, Rodríguez \& Miralles, 2015; López Facal \& Sáiz, 2016), which reproduces a national narrative containing numerous stereotypes.

The influence of national narratives in representations and accounts of the past produced by students and teachers constitutes a subjective process of identification (González \& Carretero, 2013). Forms of national identification are evident in a narrative depending on how the studentnarrative subject evolves (Plá, 2005). The influence of cultural studies and the linguistic shift of history have led to researchers on the teaching of history paying more and more attention to discourse analysis and the presence of students as narrators as well as to the ways in which their ideas about the past are expressed (Seixas, 2000; Barton \& Levstik, 2004; Barton, 2010). In this regard, the degree to which, and the way in which, the first person of the plural is used is shown to be relevant, be it the subject pronoun "we" or the possessive "our" with which the protagonists are identified in their historical narrative. In addition, making explicit essentialist references to Spain or to Spaniards of the Middle Ages, or earlier periods of history, is of significance. These indicators constitute a specific feature of national narratives and have also been documented among pupils at baccalaureate level (16-18 years of age) (Sáiz \& López Facal, 2012).

The analysis of social representations of the past produced by trainee teachers is, in our opinion, a relevant object for study. It is important to determine what they know and how they communicate and explain this knowledge in order to foresee to what degree certain stereotypes may be present in their future teaching. Detecting these elements at an early stage may serve to improve history teaching and the understanding of social phenomena. In this context, the concept of the schematic narrative template employed by Wertsch (2002) gains significance as a cultural mediation tool generated and distributed among a social group, which is perfectly applicable to historical narratives as national narratives (Carretero, López, González \& Rodríguez-Moneo, 2012). A powerful narrative of mediation is present in the knowledge and historical memories of students and/or teachers due to the significance of national narratives in the school curriculum and textbooks. Carrying out an analysis of the national stereotypes contained in these narratives enables us to understand the internal structure of the historical discourse of future teachers and 
to act upon them in order to avoid the continuation of a model of history education based on rote learning and the passivity of the learner.

\section{Research Methodology}

\section{Objectives}

The main aim of this research is to analyse accounts of the history of Spain as narrated by trainee teachers studying a Primary Education Degree in order to identify both their historical knowledge and the structure of their narratives. This aim can be broken down into three points:

1. To analyse and describe the argumentative structure of their accounts of the history of Spain.

2. To identify the characters, events and processes which they consider to be most relevant in the history of Spain.

3. To detail the sources of historical knowledge which students consider to be most relevant in forming knowledge on the history of Spain.

\section{Participants}

The sample employed was incidental in nature. One hundred and three students took part from a class on teaching methodology for the social sciences in the third year of a Primary Education degree at the University of Murcia (Spain) during the 2016-2017 academic year. As far as the demographic variables of the sample are concerned, three quarters of the participants were women (table 1 ) and $83 \%$ were either 20 or 21 years of age (table 2 ).

TABLE 1. Sex of the participants in the research

\begin{tabular}{|l|r|r|}
\hline Sex & Frequency & Percentage \\
\hline Male & 26 & 25.2 \\
\hline Female & 77 & 74.8 \\
\hline Total & 103 & 100.0 \\
\hline
\end{tabular}

TABLE 2. Age of the participants in the research

\begin{tabular}{|l|r|r|}
\hline Age & Frequency & Percentage \\
\hline 19 & 9 & 8.7 \\
\hline 20 & 57 & 55.3 \\
\hline 21 & 28 & 27.2 \\
\hline 22 & 3 & 2.9 \\
\hline 23 & 1 & 1.0 \\
\hline 24 & 2 & 1.9 \\
\hline 28 & 1 & 1.0 \\
\hline 30 & 1 & 1.0 \\
\hline 41 & 1 & 1.0 \\
\hline Total & 103 & 100.0 \\
\hline
\end{tabular}




\section{Method}

A design based on the so-called non-experimental methods was employed, focusing on the empirical and systematic search for a phenomenon, the independent variables of which have already occurred or are not able to be manipulated (Kerlinger, 2002). The aim was to gain knowledge of a reality in order to then obtain explicatory models regarding the characteristics of the historical discourse of future primary school teachers. The analysis of the data combines a quantitative and qualitative approach in order to generate proposals and action strategies, which are normally considered to be complementary in research on history education (Ashby, 2004; Barca, 2005; Barton, 2012). Although combining a qualitative and qualitative analysis, the quantitative prevailed.

For the quantitative analysis, the categories for which it was possible were coded using the SPSS v.21.0 statistical package: analysis of frequencies, averages, percentages and bivariate correlations. The handling of qualitative data analyses the conceptual complexity and the discourse of the narratives. The process of qualitative analysis has given meaning to the textual information by following strategies derived from grounded theory (Corbin \& Strauss, 2008), which has been employed in other research on history education (Barca, 2011; Barca \& Schmidt, 2013). The validity of qualitative research depends on how representative the data, the theoretical basis and its analysis and interpretation are (Anguera, 1998).

Tools for data gathering and categorisation

First of all, as a means of gathering data, the university students were asked to write a text synthesizing the history of Spain. This account was to be written during a class on social science teaching at the beginning of the academic year (September-October 2013). They were instructed to write a maximum of one page and were given no indication regarding content or form in order to minimize interference in their work. The second stage of the data gathering process consisted of asking the students to assess the sources of their historical knowledge via the use of a list (table 3), preceded by the following phrase: Below, you have a list of sources of information from which you may have learnt about history. On a scale of 1 to 5, assess how much you have learnt from them (with 1 being that you have learnt nothing and 5 that you have learnt a lot).

TABLE 3. Sources of historical knowledge in the data gathering method

\begin{tabular}{|l|l|l|l|l|l|}
\hline Teachers' lessons & 1 & 2 & 3 & 4 & 5 \\
\hline Textbooks used in class & 1 & 2 & 3 & 4 & 5 \\
\hline Family & 1 & 2 & 3 & 4 & 5 \\
\hline Friends & 1 & 2 & 3 & 4 & 5 \\
\hline Cinema and TV series & 1 & 2 & 3 & 4 & 5 \\
\hline TV documentaries & 1 & 2 & 3 & 4 & 5 \\
\hline Videogames & 1 & 2 & 3 & 4 & 5 \\
\hline History books and novels & 1 & 2 & 3 & 4 & 5 \\
\hline History dissemination magazines & 1 & 2 & 3 & 4 & 5 \\
\hline Visits to museums or places of historical interest & 1 & 2 & 3 & 4 & 5 \\
\hline National or local festivals and celebrations & 1 & 2 & 3 & 4 & 5 \\
\hline Comics & 1 & 2 & 3 & 4 & 5 \\
\hline
\end{tabular}


The validity of this method of gathering data (an account of historical synthesis) in order to obtain the proposed objectives was based on several research projects, for example those of Bage (1999); Barton \& Levstik (2004), López, Carretero \& Rodríguez-Moneo, (2014); Henríquez \& Ruiz (2014) and VanSledright (2008). These types of narratives are an appropriate tool for evaluating historical methodological concepts and analysing the social representation of the past and its relationship to collective memory. The qualitative data was gathered and analysed using the ACCESS database. The quantitative data was coded and then analysed with the SPSS v.21.0 statistical package.

In order to analyse the contents of the narratives, three categories were defined: historical processes, historical events and historical characters. The historical processes category refers to relatively long periods of time which have been conceptualized from a historiographical point of view (for example, the Civil War, the Transition and the Reconquista). The historical events category refers to specific events (such as the Muslim invasion of the Iberian Peninsula or the abdication of Juan Carlos I). As far as the category of historical characters is concerned, the appearance of specific names throughout the narratives has been detailed.

\section{Results}

\section{Principal markers and historical processes in the narratives}

The most remarkable aspect of the results is that the students' narratives show a low level of complexity. More than $50 \%$ of the accounts are limited to lists of processes, events or characters without a coherent narrative structure and with historical processes outnumbering the other categories (events and characters). More than $50 \%$ of the narratives include five or more historical processes. The students were much more capable of remembering processes, such as the Roman period, the Reconquista or the Civil War, than the most important events or characters of these processes. $53 \%$ of the narratives mention just one character, or none, whereas almost $60 \%$ mention one historical event, or none (tables 4, 5 and 6 ).

TABLE 4. Number of historical processes mentioned in the students' narratives

\begin{tabular}{|l|c|c|}
\hline Number of processes & Frequency & Percentage \\
\hline 0 & 11 & 10.7 \\
\hline 1 & 9 & 8.7 \\
\hline 2 & 12 & 11.7 \\
\hline 3 & 8 & 7.8 \\
\hline 4 & 8 & 7.8 \\
\hline 5 & 15 & 14.6 \\
\hline 6 or more & 40 & 38.8 \\
\hline Total & 103 & 100.0 \\
\hline
\end{tabular}


TABLE 5. Number of historical events mentioned in the students' narratives

\begin{tabular}{|l|c|c|}
\hline Number of facts & Frequency & Percentage \\
\hline 0 & 27 & 26.2 \\
\hline 1 & 33 & 32.0 \\
\hline 2 & 20 & 19.4 \\
\hline 3 & 12 & 11.7 \\
\hline 4 & 10 & 9.7 \\
\hline 6 or more & 1 & 1.0 \\
\hline Total & 103 & 100.0 \\
\hline
\end{tabular}

TABLE 6. Number of characters mentioned in the students' narratives

\begin{tabular}{||l|r|r|}
\hline Number of characters & Frequency & Percentage \\
\hline 0 & 32 & 31.1 \\
\hline 1 & 23 & 22.3 \\
\hline 2 & 18 & 17.5 \\
\hline 3 & 6 & 5.8 \\
\hline 4 & 10 & 9.7 \\
\hline 5 & 6 & 5.8 \\
\hline 6 or more & 8 & 7.8 \\
\hline Total & 103 & 100.0 \\
\hline
\end{tabular}

The lack of narrative and argumentative wealth of the accounts has already been analysed in previous studies (Sáiz, 2015; Sáiz \& Gómez, 2016). We are of the opinion that one of the most immediate causes of this situation is the reproduction of a traditional educational model regarding history, based on a linear and simplified reading of the construction of the nation, which places more emphasis on the rote learning of processes, events and characters than on reasoning, the analysis of causes and the understanding of changes and unchanging situations.

We believe that this model is due to a number of factors, including the prevalence of expository masterclasses, the generally passive role of pupils in the classroom, the overuse of textbooks and exams as the main resources and means of assessment (Cuesta, 1998; Gómez, Rodríguez \& Mirete, 2016; Miralles \& Martínez, 2008). According to Merchán (2001), teaching routines consisting of the explanation and organisation of contents are frequently used in history classes as control and order strategies and to fulfil requirements related to exams. Studies such as that of Sáiz \& Fuster (2014) demonstrate that these routines are still practiced. Indeed, many of the elements of the disciplinary code of history still survive: 
... the set of ideas, values, suppositions, rules and routine practices (of an express or tacit nature), which guide the professional practice of teachers. To sum up, the ensemble of ideas, discourse and ways of making history teaching relevant within the framework of school (Cuesta 2002: 29).

When analysing the elements chosen by the students in their narratives (tables 7, 8 and 9), it can be observed that for Ancient history and the Middle Ages a basic thematic thread is maintained based on the construction of a national historical narrative: the classical origins (the Roman period), the cultural wealth contributed by Al-Andalus and the social and political foundations of the Christian kingdoms with the Reconquista as the pivot of territorial articulation. These three concepts (Romanisation, Al-Andalus and the Reconquista) are often interrelated.

However, in the students' narratives, few events and characters are provided, with the exception of the Catholic Monarchs, who appear in more than $50 \%$ of the narratives. Only $6.8 \%$ made mention of the Muslim invasion and $1.8 \%$ referred to the Battle of Las Navas de Tolosa. As far as characters are concerned, 3\% mentioned Abd-ar-Rhaman III, while only 1\% mentioned Boabdil, the last Muslim king of Granada. The Modern Age is basically reduced to two themes: the discovery of America and the Empire, along with the two most significant monarchs of the time (Charles V and Philip II).

After the Modern Age, dates, names and monarchs begin to gain more prominence in textbooks (Gómez, Rodríguez \& Simón, 2013), which is reflected in the narratives we have analysed. As far as the Contemporary Age is concerned, the Civil War/Franco regime and the transition to democracy are the most significant topics. For the $19^{\text {th }}$ century, the number of events (the Cádiz Cortes, the Constitution of 1812, Salic Law) and characters (Amadeo I, Isabel II) mentioned is significant, compared to the lack of references to historical processes. This can be related to the topics taught in the last year of baccalaureate (16-18 years of age), which focus mainly on the $19^{\text {th }}$ and $20^{\text {th }}$ centuries and are of importance for university access exams.

TABLE 7. Historical processes[periods] mentioned by students in the narratives with percentages

\begin{tabular}{|l|c|l|c|}
\hline PROCESSES [Periods] & Percentage & PROCESSES [Periods] & Percentage \\
\hline Civil War & 66.02 & The Six Revolutionary Years & 4.85 \\
\hline The Franco Regime & 55.34 & The Iberians & 3.88 \\
\hline Al-Andalus & 52.43 & The Christian Kingdoms & 3.88 \\
\hline The Romanisation Of Spain & 39.81 & The Industrial Revolution & 3.88 \\
\hline The Reconquista & 37.86 & The Economic Crisis & 2.91 \\
\hline The 2 ${ }^{\text {nd }}$ Republic & 30.10 & The Appearance Of The Bourgeoisie & 1.94 \\
\hline The Transition & 29.13 & The 1st Republic & 1.94 \\
\hline The Spanish Empire & 6.80 & The Restoration & 1.94 \\
\hline $\begin{array}{l}\text { The Peninsular War “Guerra De La } \\
\text { Independencia" }\end{array}$ & 5.83 & Basque And Catalan Nationalism & 1.94 \\
\hline The Visigoths & 4.85 & Enlightened Absolutism & 0.97 \\
\hline
\end{tabular}


TABLE 8. Historical characters mentioned by students in their narratives with percentages

\begin{tabular}{|l|c|l|c|}
\hline CHARACTERS & Percentage & CHARACTERS & Percentage \\
\hline The Catholic Monarchs & 53.40 & Charles lii & 4.85 \\
\hline Franco & 27.18 & Napoleon & 3.88 \\
\hline Juan Carlos I & 14.56 & Abd-Ar-Rhaman lii & 2.91 \\
\hline Charles V & 13.59 & Amadeo I & 2.91 \\
\hline Ferdinand Vii & 12.62 & Joanna 'The Mad' Of Castile & 1.94 \\
\hline Isabel li & 12.62 & Philip I Of Castile 'The Handsome' & 1.94 \\
\hline Felipe Vi & 9.71 & Boabdil & 0.97 \\
\hline Christopher Columbus & 6.80 & Cervantes & 0.97 \\
\hline Primo De Rivera & 5.83 & Espartero & 0.97 \\
\hline Adolfo Suárez & 5.83 & Riego & 0.97 \\
\hline Philip li & 4.85 & & \\
\hline
\end{tabular}

TABLE 9. Historical events mentioned by students in their narratives with percentages

\begin{tabular}{|l|c|}
\hline EVENTS & Percentage \\
\hline The Discovery Of America & 41.75 \\
\hline The Constitution Of 1812 & 34.95 \\
\hline The Cádiz Cortes & 17.48 \\
\hline The Coup D'état Of 1936 & 10.68 \\
\hline The Muslim Invasion & 6.80 \\
\hline Salic Law & 6.80 \\
\hline The Abdication Of Juan Carlos I & 3.88 \\
\hline The Battle Of Las Navas De Tolosa & 1.94 \\
\hline The Hundred Thousand Sons Of Saint Louis & 0.97 \\
\hline The Constitution Of 1978 & 0.97 \\
\hline The Caretaker Government & 0.97 \\
\hline
\end{tabular}

These narratives demonstrate a historical account based on a linear and simplistic view of the past, one which is in line with romantic objectives of history (Carretero et al., 2013), corresponding to the creation of nation states (see, for example, Carretero \& Kriger, 2004; Hobsbawm, 1997; and VanSledright, 2008, among others). The teaching of history from this perspective is based on the transference of a collective memory which exalts the value of the founding fathers and heroes of a nation (VanSledright, 2011). Learning based on this type of linear narrative is usually combined with a low level of cognitive requirements, as has been proved in other studies of exams and textbooks (Gómez \& Miralles, 2013 and 2015; Sáiz, 2013), thereby leading to an education in history which lacks the ethical dimension necessary for living in a democratic society. 
With the exception of the modernisation carried out by some innovative minority groups in education during the 1980s and 1990s, as a result of the transition to democracy, such as Germanía-75 and Historia 13-16, subsequent legislation in Spain has limited, or extinguished, attempts at renovation. Indeed, the latest conservative educational reform has maintained, and even accentuated, the positivist perspective of history (López, 2014). In primary education (from 6 to 12 years of age), pupils are required to assume a narrative of the history of Spain, and of their autonomous community ranging from prehistory to the present day. During secondary education (from 12 to 16 years of age), in addition to the Spanish perspective, more importance is given to a Eurocentric point of view, particularly from the Middle Ages onwards. This perspective causes conflicts between the recentralizing efforts of the national government and the centrifugal emphasis of the autonomous communities with their own languages, which assume a similar position of identifying their community as an undivided nation or proto-nation dating back to ancient times (López Facal, 2010). In both cases, in the history taught and learnt obsolete concepts are maintained, which are far from a practice based on posing problems which force students to mobilise skills or abilities for social analysis. This form of history is alien to the practical use of serving as moral guidance for life (Rüsen, 2015).

\section{Traditional sources of knowledge}

The narratives we analysed show a poor standard of discursive structure and are extremely traditional in their contents. The students' assessment of the sources of knowledge from which they believe they have learnt history continues along these traditional lines (table 10). The two highest-ranked sources of knowledge are teachers in the classroom and textbooks, while the students consider that other, more informal, sources, such as comics and videogames, have taught them little or nothing about history. Neither of the latter two sources obtained the highest mark in any of the 103 questionnaires analysed.

TABLE 10. An evaluation of sources of historical knowledge by trainee teachers (with 1 being the lowest mark and 5 the highest)

\begin{tabular}{|l|c|c|c|c|}
\hline & \multicolumn{1}{l|}{ N } & Minimum & Maximum & Average \\
\hline Teachers In The Classroom & 103 & 1.00 & 5.00 & 3.6602 \\
\hline Textbooks & 103 & 1.00 & 5.00 & 3.4175 \\
\hline Museums & 103 & 1.00 & 5.00 & 3.2718 \\
\hline Cinema and TV Series & 103 & 1.00 & 5.00 & 3.1262 \\
\hline Documentaries & 103 & 1.00 & 5.00 & 2.9320 \\
\hline Family & 103 & 1.00 & 5.00 & 2.9029 \\
\hline Websites & 103 & 1.00 & 5.00 & 2.8932 \\
\hline History Books & 103 & 1.00 & 5.00 & 2.8932 \\
\hline Local Festivals & 103 & 1.00 & 5.00 & 2.8058 \\
\hline Friends & 103 & 1.00 & 4.00 & 2.0680 \\
\hline History Dissemination Magazines & 103 & 1.00 & 5.00 & 1.8544 \\
\hline Videogames & 103 & 1.00 & 4.00 & 1.5825 \\
\hline Comics & 103 & 1.00 & 4.00 & 1.5534 \\
\hline
\end{tabular}


The answers in this case were quite coherent internally, as can been observed in tables 11,12 and 13, which show bivariate correlations between different items (Kendall's Tau-b has been used due to the ordinal nature of the variables analysed). There is a moderate correlation (0.3) between the evaluation made by the students of the teachers' classes and that of textbooks as sources of information. The students scored both items in a similar way. Therefore, a statistically significant correlation exists between them. There is also a moderate correlation (0.25) between the evaluation of museums and of cinema and TV series (items with a medium-high score among the trainee teachers). There is also a medium to high evaluation of comics and videogames as sources of information (0.48).

TABLE 11. Correlation of Kendall's Tau-b between the evaluation of teachers' classes and of textbooks

\begin{tabular}{||l|l|c|c|}
\hline \multicolumn{2}{|l|}{} & $\begin{array}{l}\text { Teachers' } \\
\text { classes }\end{array}$ & Textbooks \\
\hline \multirow{3}{*}{ Teachers' classes } & Correlation coefficient & 1.000 & $.301^{* *}$ \\
\cline { 2 - 4 } & Sig. (bilateral) &. & .000 \\
\cline { 2 - 4 } & $\mathrm{N}$ & 103 & 103 \\
\hline Textbooks & Correlation coefficient & $.301^{* *}$ & 1.000 \\
\cline { 2 - 4 } & Sig. (bilateral) & .000 &. \\
\cline { 2 - 4 } & N & 103 & 103 \\
\hline$* *$ The correlation is significant at 0.01 (2-tailed). & & \\
\hline
\end{tabular}

TABLE 12. Correlation of Kendall's Tau-b between the evaluation of videogames and comics as sources of information

\begin{tabular}{|c|c|c|c|}
\hline & & Videogames & Comics \\
\hline \multirow[t]{3}{*}{ Videogames } & Correlation coefficient & 1.000 & $.486^{* *}$ \\
\hline & Sig. (bilateral) & . & .000 \\
\hline & $\mathrm{N}$ & 103 & 103 \\
\hline \multirow[t]{3}{*}{ Comics } & Correlation coefficient & $.486^{* *}$ & 1.000 \\
\hline & Sig. (bilateral) & .000 & . \\
\hline & $\mathrm{N}$ & 103 & 103 \\
\hline
\end{tabular}


TABLE 13. Correlation of Kendall's Tau-b between the evaluation of museums and the use of cinema/TV series

\begin{tabular}{||l|l|c|c|}
\hline \multicolumn{2}{|c|}{} & Museums & $\begin{array}{l}\text { Cinema / TV } \\
\text { series }\end{array}$ \\
\hline \multirow{3}{*}{ Museums } & Correlation coefficient & 1.000 & $.256^{* *}$ \\
\cline { 2 - 4 } & Sig. (bilateral) &. & .002 \\
\cline { 2 - 4 } & $\mathrm{N}$ & 103 & 103 \\
\hline \multirow{3}{*}{$\begin{array}{l}\text { Cinema / TV } \\
\text { series }\end{array}$} & Correlation coefficient & $.256^{* *}$ & 1.000 \\
\cline { 2 - 4 } & Sig. (bilateral) & .002 & \\
\cline { 2 - 4 } & $\mathrm{N}$ & 103 & 103 \\
\hline \multirow{2}{*}{$* *$ The correlation is significant at 0.01 (2-tailed). } & & \\
\hline
\end{tabular}

\section{Discussion and Conclusions}

In an earlier study of the most common concepts found in primary school textbooks (Gómez, Rodríguez \& Simón, 2013), many of the same elements as those contained in the trainee teachers' narratives can be identified: "Romanisation", Al-Andalus", the "Christian Kingdoms", the "Civil War", the "Republic" and the "Transition". The Middle Ages and the Contemporary Age are the periods in which processes, events and characters are most interconnected. In this context, the concept of the schematic narrative template employed by Wertsch (2002) must be remembered in reference to the narrative influence existing in the knowledge and historical memories of students and/or teachers due to the emphasis of national narratives in the curriculum and in school textbooks.

With regard to medieval times, the combination of the Christian kingdoms and Al-Andalus has become a key element of the national narrative. From the end of the 19th century, the Christian expansion, which was interpreted as a reconquest, or "repopulation", became integrated into the metanarrative and foundational myth of Spanish identity. At the same time, the Muslim period and territory of Al-Andalus is considered from a secondary perspective, more in cultural terms, as a multicultural coexistence full of cultural splendour. Modern-day Spanish historiography has not dispelled this terminology. The polysemy and usefulness of the term "Reconquista" is defended in order to describe the phenomenon and period of Christian expansion and conquest in Islamic territories. Although its nature of retrospective ideological justification is recognized, no alternative term has been created which is able to encompass such a broad period of the history of the Peninsula as this (García-Fitz, 2010; Ríos, 2013).

The information contained in the narrative continues to be, above all, political in nature, a discourse based on the construction of the historical narrative of Spain. Both Wineburg (2001) and VanSledright (2011) have pointed out the limitations implied by a linear approach to the teaching of history based on the construction of the nation which attempts to compete with the culture of mass consumption. The focus on historical contents, which have the aim of consolidating a collective memory of the nation, instils a passive role in the learner. Furthermore, as VanSledright (2011) points out, the teacher becomes a narrator of the achievements of the nation by calling attention to their most exciting aspects in an attempt to interest his/her students, who are more accustomed to audio-visual consumption. 
This leads to certain difficulties arising, such as the low cognitive level required by this type of teaching and the resistance of learners in multicultural contexts when faced with a reading of history which has been written beforehand from a specific perspective. Several studies have shown that in the United States the events and characters taken as reference points in the national narrative were different depending on the ethnic or geographic origin of the learner. While, for some, George Washington, Kennedy, the Declaration of Independence and the Civil War were of importance, for others Martin Luther King, Malcolm X, the civil rights movement and the abolition of slavery were more relevant (VanSledright, 2011).

The results indicate that trainee teachers have not received an appropriate level of education in terms of history, either in substantive contents or in developing the historian's syntactic skills, processes and disciplinary concepts that are central to thinking historically. Therefore, it is difficult to see how they could be in a position to teach history with the minimum levels of disciplinary and educational, knowledge, both the syntactic and the substantive 'factual' body of knowledge, at least according to the standards currently accepted by educational researchers in the field of social sciences and history education (Wineburg, 2001; Barton \& Levstik, 2004; VanSledright, 2014). The problem not only derives from the design of the study plans for primary teaching degrees in Spain, in which subject-based material is not taught but also from another underlying factor is the fact that history, in both primary and secondary stages of education, is taught in an irregular and insufficient manner with rote learning and methods based on the reproduction of factual and conceptual contents being predominant.

Note that students have, in the past, memorised historical data which they can no longer recall. School history is still presented as something to be studied and reproduced in the generic form of academic texts. These are, on the whole, based on a national and Eurocentric narrative. There is not evidence that the introduction of the educational paradigm proposing the development of fundamental skills does has alleviated this deficiency. The traditional, embedded positivistic historical disciplinary code maintains pride of place in school textbooks (Gómez, 2014; Gómez \& Miralles, 2016; Sáiz, 2013; Sáiz \& Colomer, 2014), in the classroom and in the style of examinations (Gómez \& Miralles, 2013 and 2015; Sáiz \& Fuster, 2014).

Rüsen's analysis and proposals $(2005 ; 2015)$ highlight the importance of converting history into useful knowledge with the aim of ethically orienting personal behaviour. Furthermore, the educational potential of the teaching of skills relating to strategic contents and historical thought in primary education has been widely documented. Cooper's (2013) and VanSledright's (2002) studies show the way in which the use of sources, research methods, reflection and historical reasoning come into play.

However, the conception of history as a received body or canon of closed, uncontestable given substantive factual knowledge and not as an intellectual subject for the creation and construction of historical knowledge is an idea that is deeply rooted in many countries. Here the teaching of history is based on a linear account of past events which have previously been selected by the official syllabus, the textbook, the school's planning and, finally, by the teacher. It is necessary to carry out a transversal intervention with the aim of increasing the presence of history teaching (in terms of substantive contents and historical skills) at foundational stages of education, as well as in the training of future primary and secondary teachers. The deficiencies documented in this paper among students of a primary teaching degree confirm the need for reflection on the way teachers are trained beyond educational concepts and generic cognitive aspects, in order to reinforce their level of history education. 


\section{Correspondence}

Cosme J. Gómez Carrasco

cjgomez@um.es

Ramón López Facal

ramon.facal@usc.es

Jorge Sáiz Serrano

Jorge.saiz@uv.es

\section{References}

Álvarez Junco, J. (coord.) (2013). Las historias de España. Visiones del pasado y construcción de identidad, Madrid: Crítica-Marcial Pons.

Anguera, M. T. et al. (1998). Métodos de investigación en psicología. Madrid: Síntesis.

Ankersmit F. R. (2001). Historical representation. Stanford University Press.

Ashby, R. (2004). Developing a concept of historical evidence: Students' ideas about testing singular factual claims. International Journal of Historical Learning, Teaching and Research 4 (2), pp. 44-55.

Bage, G. (1999). Narrative Matters. Teaching and Learning History through story. New York: Routledge.

Barca, I. (2005). "Till new facts are discovered": Students' ideas about objectivity in history. In: Ashby, R., Gordon, P. \& P. Lee (ed.). International review of history education, Vol. 4: Understanding history: Recent research in history education, (pp. 68-82), New York: RoutledgeFalmer.

Barca, I. (2011). La evaluación de los aprendizajes en historia. In Miralles, P., Molina, S. \& Santisteban, A. (ed.) La evaluación y el proceso de enseñanza y aprendizaje de las ciencias sociales. Murcia: AUPDCS, pp. 107-120.

Barca, I. \& Schmidt, Mª A. (2013). La consciencia histórica de los jóvenes brasileños y portugueses y su relación con la creación de identidades nacionales., Educatio Siglo XXI, 31,(1), pp. 25-45.

Barton, K. (2010). Investigaciones sobre las ideas de los estudiantes acerca de la historia. Enseñanza de las Ciencias Sociales, 9, pp. 97-114.

Barton, K. C. (2005). 'Best not to forget them': Adolescents' judgments of historical significance in Northern Ireland. Theory and Research in Social Education, 33, pp. 9-44.

Barton, K. C. (2012). Applied research: Educational research as a way of seeing. In: McCully, A., G. Mills, G. C. Van Boxtel, C. (ed.). The professional teaching of history: UK and Dutch perspectives, Coleraine, Northern Ireland: History Teacher Education Network, pp. 1-15.

Barton, K. \& Levstik, L. (2004). Teaching History for the Common Good. New Jersey: Lawrence Erlbaum.

Carretero, M. \& López, C. (2010). The Narrative mediation on historical remembering. In: Salvatore, S. Valsiner, J., Simon, J. T. \& A. Gennaro, A. (eds.). Yearbook of Idiographic Science (Vol. 3). Rome: Firera \& Liuzzo, pp. 285-294. 
Carretero, M. \& Van Alphen, F. (2014). Do Master Narratives Change Among High School Students? A Characterization of How National History Is Represented. Cognition and Instruction, 32 (3), pp. 290-312, DOI: 10.1080/07370008.2014.919298.

Carretero, M., López, C., González, M. F. \& Rodríguez-Moneo, M. (2012). Students' historical narratives and concepts about the nation. In: Carretero, M., Asensio, M. \& Rodríguez-Moneo, $\mathrm{M}^{\mathrm{a}}$ (eds.), History Education and the Construction of National Identities. Charlotte CT: Information Age Publishing, pp. 153-170.

Chapman, A. (2011). Taking the perspective of the other seriously? Understanding historical argument. Educar em Revista 42, pp. 95-106.

Cooper, H. (2013) (ed.). Teaching History Creatively. Learning to Teach in the Primary School Series. New York: Routledge.

Corbin, J. \& Strauss. A. (2008). Basics of qualitative research. Techniques and procedures for Developing Grounded Theory. Thousand Oaks, CA: Sage.

Fülöp, E. \& Lázsló, J. (2013). Emotional Processes in Elaborating a Historical Trauma in the Daily Press. In: Cabecinhas, R. \& Abadia, L. (eds.). Narratives and Social Memory. Theoretical and methodological approaches. Braga: Universidade Do Minho, pp. 46-60.

García-Fitz, F. (2010). La Reconquista, Granada: Universidad de Granada.

Gómez, C. J. (2014). Pensamiento histórico y contenidos disciplinares en los libros de texto. Un análisis exploratorio de la Edad Moderna en $2^{\circ}$ de la ESO. Ensayos. Revista de la Facultad de Educación de Albacete, 29(1), pp. 131-158.

Gómez, C. J. \& Miralles, P. (2013). Los contenidos de ciencias sociales y las capacidades cognitivas en los exámenes de tercer ciclo de educación primaria ¿Una evaluación de competencias? Revista complutense de educación, 24 (1), pp. 91-121.

Gómez, C. J. \& Miralles, P. (2015). ¿Pensar históricamente o memorizar el pasado? La evaluación de los contenidos históricos en la educación obligatoria en España. Revista de Estudios Sociales, 52, pp. 52-68.

Gómez, C. J. \& Miralles, P. (2016). Développement et évaluation des compétences historiques dans les manuels scolaires. Une étude comparative France-Espagne. Spirale. Revue de Recherches en Education, 58, pp. 53-66.

Gómez, C. J., Rodríguez, R. A. \& Simón, M. (2013). 'Conocimientos y saberes escolares de Ciencias Sociales en tercer ciclo de Primaria'. In Prats, J., López Facal, R. \& Barca, I. (eds.), Historia e identidades culturales, Braga, Universidade do Minho, pp. 600-613.

González, Ma F. \& Carretero, M. (2013). Historical narratives and arguments in the context of identity conflicts. Estudios de Psicología, 34 (1), pp. 73-82.

Kerlinger, F. N. (2002). Investigación del comportamiento. Métodos de investigación en ciencias sociales. Mexico: McGraw-Hill.

Henríquez, R. \& Ruíz, M. (2014). Chilean students learn to think historically: Construction of historical causation through the use of evidence in writing. Linguistics and Education, 25, pp. 145-167.

Lázló, J. (2008). The Science of Stories: An Introduction to Narrative Psychology. London: Routledge.

Lévesque, S. (2008). Thinking Historically. Educating Students for the $21^{\text {st }}$ Century, Toronto: University of Toronto Press. 
Levstik, L. \& Barton, K. (2008). Doing History, Investigating with Children in Elementary and Middle Schools. New York: Routledge.

Liu, J. H. (2013). Narratives and Social Memory from the perspective of Social Representations of History. In Cabecinhas, R. \& Abadia, L. (eds). Narratives and Social Memory. Theoretical and methodological approaches. Braga: Universidade Do Minho, pp. 11-24.

López, C.; Carretero, M. \& Rodríguez-Moneo, Ma (2014). Conquest or reconquest? Students' Conceptions of Nation Embedded in a Historical Narrative. Journal of the Learning Sciences. 1-33, DOI: 10.1080/10508406.2014.919863.

López Facal, R. (2010). Nacionalismos y europeísmos en los libros de texto: identificación e identidad nacional. Clío y asociados: la historia enseñada, 14, pp. 9-33.

López Facal, R. (2014). La LOMCE y la competencia histórica. Ayer, 94, pp. 273-285.

López Facal, R. \& Sáiz, J. (2016). "History Education and Nationalism Conflicts in Spain". In Guyver, R. (ed.), Teaching History and the Changing Nation State. Transnational and Intranational Perspectives, London: Bloomsbury.

McAdams, D. P. (2006). The role of narrative in personality psychology today. Narrative Inquiry, 16 (1), pp. 11-18.

Monte-Sano, Ch. (2010). Disciplinary literacy in history: An exploration of the historical nature of adolescents' writing. The Journal of the Learning Sciences 19 (4), pp. 539-568.

Plá, S. (2005). Aprender a pensar históricamente. La escritura de la historia en el bachillerato. Mexico: Plaza y Valdés.

Ríos, M. (2013). La Reconquista en la historiografía española contemporánea. Madrid: Sílex.

Rüsen, J. (2005). History: Narration, Interpretation, Orientation, New York, Berghahn.

Rüsen, J. (2015). Teoria da História. Uma teoria da história como ciencia. Curitiba (Brazil): Ed. Universidade Federal do Paraná.Sáiz, J. (2013). Alfabetización histórica y competencias básicas en libros de texto de historia y en aprendizaje de los estudiantes. Didáctica de las Ciencias Experimentales y Sociales 27, pp. 43-66.

Sáiz, J. (2015). Educación histórica y narrativa nacional. Valencia: Doctoral thesis.

Sáiz, J. \& Colomer, J. C. (2014). ¿Se enseña pensamiento histórico en libros de texto de Educación Primaria? Análisis de actividades de historia para alumnos de 10-12 años. CLIO. History and History Teaching, 40.

Sáiz, J. \& Gómez, C. J. (2016). Investigando el pensamiento histórico y narrativo en la formación del profesorado: fundamentos teóricos y metodológicos. REIFOP, 19 (1), pp. 175-190.

Sáiz, J. \& Fuster, C. (2014). Memorizar historia sin aprender pensamiento histórico. Las PAU de Historia de España. Investigación en la escuela, 84.

Sáiz, J. \& López Facal, R. (2012). Aprender y argumentar España. La visión de la identidad española entre el alumnado al finalizar bachillerato. Didáctica de las Ciencias Experimentales y Sociales, 26, pp. 95-120.

Sáiz, J. \& López Facal, R. (2015). Competencias y narrativas históricas. El pensamiento histórico de estudiantes y futuros profesores. Revista de Estudios Sociales, 52, pp. 87-101. 
Seixas, P. (2000). Schweigen! Die Kinder! or, Does Postmodern History Have a Place in the Schools? In: Stearns, P. Seixas, P. \& S. Wineburg, S. (ed.). Knowing, Teaching and Learning History. National and International Perspectives. New York-London: New York University Press, pp. 19-37.

VanSledright, B. A. (2002). In Search of America's Past. Learning to Read History in Elementary School. New York: Teacher College Press.

VanSledright, B, A. (2008). Narratives of Nation-State, Historical Knowledge and School History Education. Review of Research in Education, 32 (1), pp.109-146.

VanSledright, B. A. (2011). The Challenge of Rethinking History Education. On Practice, Theories, and Policy. New York: Routledge.

Wertsch, J. V. (2002). Voices of Collective Remembering. Cambridge: Cambridge University Press.

Wineburg, S. (2001). Historical Thinking and Other Unnatural Acts: Charting the Future of Teaching the Past. Philadelphia, Temple University Press. 